\title{
Penguatan Kelembagaan Badan Usaha Milik Nagari (BUM-Nag) Sebagai Upaya Peningkatan Ekonomi Nagari
}

\author{
Boni Saputra*1, Hidayatul Fajri², Pratiwi Nurhabibi ${ }^{3}$ \\ 1,2,3Program Studi Ilmu Administrasi Negara, Fakultas Ilmu Sosial, Universitas Negeri Padang \\ *e-mail: $\underline{\text { bonisaputra@fis.unp.ac.id }}{ }^{1}, \underline{\text { hidayatulfajri@fis.unp.ac.id }}^{2}, \underline{\text { pratiwi@ fis.unp.ac.id }}^{3}$
}

\begin{abstract}
Nagari-Owned Enterprises (BUM-Nag) or in most regions in other provinces known as Desa-Owned Enterprises (BUM-Des) is a manifestation of the mandate of Law Number 6 of 2014 concerning Villages, where the village government, in this case, Nagari is prosecuted accordingly Mandiri to be able to explore the wealth and potentials that exist in the Nagarinya area to be used as assets and sources of Nagari's financial income and is required to be able to carry out Nagari's financial management independently. BUM-Nag is an alternative business entity that needs to be developed to encourage the Nagari economy, with the hope of creating new economic resources for Nagari to utilize and to prosper the Nagari people's economy. This service activity aims to contribute thoughts and counseling about strengthening the BUM-Nag institution as a form of effort in improving the nagari economy. Service activities were carried out in Nagari Tabek Patah and Nagari Situmbuk, Salimpaung Subdistrict, Tanah Datar District. This activity uses the participatory rural appraisal (PRA) method, assistance, and counseling by looking at the potential possessed by Nagari as a creative business unit of the community and the potential that must be optimized. The result to be achieved from this empowerment activity is to increase the knowledge and capability or capacity of Nagari's apparatus on institutional strengthening and management of BUM-Nag as a form of effort in improving Nagari's economy.
\end{abstract}

Keywords: Institutional Strengthening, Nagari Owned Enterprise, Nagari Economy

\begin{abstract}
Abstrak
Badan Usaha Milik Nagari (BUM-Nag) atau disebagian besar daerah pada Provinsi lain dikenal dengan BUM-Des merupakan perwujudan Undang-undang Nomor 6 tahun 2014 tentang Desa, dimana pemerintah tingkat rendah yaitu Desa atau Nagari dituntut secara mandiri mampu untuk menggali dan mengoptimalkan kekayaan dan potensi yang dimiliki didaerah Nagarinya untuk dijadikan sebagai aset dan sumber pemasukan keuangan Nagari, serta dituntut mampu melaksanakan pengelolaan keuangan Nagari secara mandiri. BUM-Nag salah satu bentuk badan usaha alternatif yang perlu mendapat perhatian khusu dan dikembangkan untuk meningkatkan perekonomian Nagari, dengan tujuan bahwa lahirnya Bum-Nag dapat menciptakan sumber daya ekonomi baru bagi Nagari yang dimanfaatkan untuk mensejahterakan ekonomi masyarakat Nagari. Kegiatan pengabdian bertujuan untuk sumbangsih pemikiran (sharing knowledge) dan penyuluhan tentang penguatan kelembagaan BUM-Nag sebagai wujud upaya dalam menigkatkan ekonomi nagari. Kegiatan pengabdian dilaksanakan di Nagari Tabek Patah dan Nagari Situmbuk, Kecamatan Salimpaung Kabupaten Tanah Datar. Pengabdian kepada masyarakat mengunakan metode participatory rural appraisal (PRA), pendampingan dan penyuluhan yang dilakukan dengan cara melihat potensi kekayaan yang dimiliki Nagari sebagai bentuk usaha kreatif masyarakat dan potensi yang harus di optimalkan. Hasil yang ingin dicapai pada kegiatan pemberdayaan ini adalah meningkatkan ilmu pengetahuan (capacity building) dan kemampuan atau kapasitas perangkat Nagari terhadap penguatan kelembagaan dan pengelolaan BUM-Nag sebagai bentuk upaya dalam peningkatan ekonomi Nagari.
\end{abstract}

Kata kunci: Penguatan Kelembagaan, BUM-Nag, Ekonomi Nagari

\section{PENDAHULUAN}

Pembangunan adalah salah satu diantara banyak cara yang dapat digunakan untuk meningkatkan kesejahteraan masyarakat. Nagari atau di daerah lain yang dikenal dengan istilah Desa atau Kelurahan merupakan bagian dari agen pemerintah terdekat dalam melakukan pembangunan, karena pembangunan sebuah nagari berkaitan langsung dengan masyarakat yang ada didaerahnya. Karena pada dasarnya suatu masyarakat akan lebih mudah maju dan berkembang berdasarkan dengan potensi apa yang dimilikinya dilingkungan masyarakat tersebut (Anwar, Goso, \& Adil, 2017). Dalam usaha pembangunan nagari, pemerintah pusat memberikan 
kewenangan secara langsung yang berupa sistem otonomi daerah terhadap pemerintah nagari untuk mengurusi dan mengelola daerahnya sesuai dengan karakter daerahnya sendiri. Upaya tersebut salah satunya adalah Badan Usaha Milik Nagari (BUM-Nag), dalam hal ini badan usaha tersebut tentu tergolong sebagai usaha makro dalam mendorong peningkatan perekonomian masyarakat. Eekonomi makro merupakan kajian tentang aktivitas ekonomi suatu negara (Karim, 2007). Lembaga Ekonomi yang dijalankan melalui BUMnag memiliki tujuan untuk mendorong peningkatan Pendapatan Asli Nagari sesuai dengan amanat (Undang-undang Nomor 6 Tahun 2014 Tentang Desa, 2014). Lahirnya tentang Desa secara tidak langsung telah memberikan kesempatan dan otoritas besar kepada Desa dalam rangka penyelenggaraan sistem pemerintahanya, melaksanakan program prioritas pembangunan desa, membina dan memberdayakan (Astuti, Murwani, \& Sugiharto, 2020) \& (Hadi, 2015). Pemerintah Desa dituntut untuk lebih aktif dan agresif dalam melaksanakan pengelolaan kekayaan desanya (Kolne \& Festianto, 2018).

Didin 2010 dalam (Solekhan, 2014) berpendapat bahwa, "Menjadikan posisi desa sebagai daerah otonom akan berdampak terhadap perubahan sistem pemerintahan kearah yang lebih baik. Perubahan tersebut diantaranya: (1) Perangkat otonom akan lebih leluasa dan fleksibel dalam melakukan perubahan, sehingga tantangan yang dihadapi akan dapat direspon lebih cepat dari yang sebelumnya, (2) Berbagai tugas yang dibebankan kepada satuan-satuan daerah otonom akan lebih mudah untuk dilaksanakan secara efektif dan efisien, (3) Inovasi akan lebih mudah dicapai oleh satuan-satuan daerah otonom, (4) Produktivitas daerah satuan otonom akan mudah tercapai dan tumbuhnya komitmen dan sikap moral yang tinggi." Peranan BUM-Nag sebagai instrument penguatan otonomi Nagari bermaksud untuk membantu (support) pemerintah Nagari dalam meningkatkan dan mengembangkan potensi Nagarinya sesuai dengan kewenangan dan seseaui dengan kemampuan yang dimiliki oleh Nagarinya, sementara itu BUMNag sebagai sebuah instrument kesejahteraan masyarakat seharusnya senantiasa melibatkan peran serta masyarakat nagarinya didalam pengelolaannya dengan tujuan mendorong dan meningkatkan perekonomian dan mengurangi angka tingkat pengangguran didaerahnya (Sulistyani, 2004). Dalam pelaksanaan pengelolaan BUMDes hendaknya dilakukan pemerintah desa secara bersama dengan melibatkan masyarakat yang ada di desanya (Pradesyah \& Albara, 2018). Kemampuan masyarakat dalam mengelola BUM-Nag tentunya menjadi hal penting yang harus diperhatiakan. Suatu kelembagaan akan berjalan sesuai dengan fungsinya jika ada sumber daya manusia yang mampu mengelola dan mengorganisirnya (Sofiani, Saepuloh, \& Eriswanto, 2016).

Pemerintah Desa dalam hal ini Nagari dituntut secara mandiri untuk mampu menggali kekayaan dan potensi-potensi yang ada didaerah Nagarinya untuk dijadikan sebagai aset dan sumber pemasukan keuangan Nagari, serta dituntut mampu melaksanakan pengelolaan keuangan Nagari secara mandiri. Pemerintah Nagari diharapkan untuk dapat mendinamisasi segala potensi desa untuk kesejahteraan masyarakatnya. Nagari sebagai bentuk dari satu kesatuan masyarakat yang mandiri (otonom), tentunya sedikit banyaknya memiliki potensi alam, sumber kekayaan alam dan memiliki pendapatan asli daerah untuk dikelola secara mandiri dan profesional dengan tujuan untuk meningkatkan taraf hidup dan kesejahteraan masyarakat yang ada di Nagarinya, karena pada hakikatnya masyarakat akan lebih mudah berkembang sesuai dengan potensi-potensi yang dimilikinya (Sayuti, 2011).

BUM-Nag merupakan salah satu badan usaha alternatif yang saat ini perlu untuk dikembangkan oleh setiap daerah, guna meningkatkan dan mendorong perekonomian Nagari, dengan harapan terciptanya sumber pendapatan baru dan sumber ekonomi baru bagi Nagari untuk mensejahterakan ekonomi masyarakat Nagari. Khusus untuk Nagari yang berada naungan Kabupaten Tanah Datar pemerintah kabupaten telah mengeluarkan peraturan daerah dalam bentuk (Peraturan Bupati Tanah Datar Nomor 5 Tahun 2016 tentang pedoman pendirian, pengurusan, pengelolaan dan pembubaran badan usaha milik Nagari, 2016). Setiap nagari yang terdapat pada Kabupaten Tanah Datar dituntut agar secara mandiri mampu dan memiliki BUM- 
Nag sebagai salah satu sumber dari pendapatan asli nagarinya. Sebanyak 56 Badan Usaha Milik Nagari (BUM-Nag) dari 75 BUM-Nag nagari di Kabupaten Tanah Datar, Sumatera Barat sudah memiliki kelengkapan struktur kepengurusan. Dari 56 BUM-Nag tersebut masih terdapat BUNNag yang sudah terbentuk namun belum juga beroperasi hingga saat ini. Seperti BUM-Nag yang ada di Nagari Situmbuk. Sementara permasalahan yang terjadi di Nagari Tabek Patah adalah mereka hanya fokus pada satu BUM-Nag sementara banyak potensi nagari yang seharusnya bisa dijadikan BUM-Nag.

Di Nagari Situmbuk sudah ada peraturan Nagari nomor 500/52/SK/WN-STB/2018 tetang Penetapan Pengurus Badan Usaha Milik Nagari (BUM-Nag) dan Badan Pengawas Badan Usaha Milik Nagari di Nagari Situmbuk Kecamatan Salimpaung akan tetapi hingga saat ini BUM-Nag yang dibentuk belum berjalan dan beroperasi sebagaimana mestinya, karena pihak pemerintah Nagari belum ada menganggarkan atau mengalokasikan dana untuk kegiatan BUM-Nag tersebut, dan belum adanya kejelasan terkait penyertaan modal yang dimiliki BUM-Nagnya. Sementara di Nagari Tabek Patah, mereka sudah memiliki BUM-Nag yang bernama "Tabek Makmur" dan sudah berjalan kurang lebih selama satu tahun, akan tetapi yang menjadi permasalahan adalah pihak Nagari hanya terfokus pada BUM-Nag satu bidang saja yaitu bidang usaha penjualan ATK dan jasa fotocopy, sementara Nagari Tabek Patah masih banyak memiliki potensi lainya yang bisa dikembangkan dan dikelola menjad BUM-Nag, seperti bidang pariwisata, hasil pertanian/perkebunannya.

Kedua nagari tersebut merupakan objek yang akan dituju dan menjadi sasaran dalam kegiatan pengabdian masyarakat ini. Nagari Situmbuk dan Nagari Tabek Patah masih memiliki kapasitas yang terbatas dalam merumuskan, menyusun dan mengelola suatu Badan Usaha Milik Nagari (BUM-Nag) untuk dijadikan sebagai salah satu aset dan sumber bagi pemasukan keuangan Nagari dan meningkatkan ekonomi nagari. Hal ini terjadi dikarenakan terbatasnya pengetahuan dan penguasaan aparatur dalam memahami peraturan yang ada yang lebih tinggi. Dari persolan ini pemerintah Nagari tentunya menyadari bahwa perlu adanya peningkatan fungsi, tugas, serta peningkatan keterampilan dan pengetahuan, serta perilaku dan sikap "capacity building" dari aparatur Nagari untuk membuat solusi dalam bentuk produk yaitu rancangan peraturan nagari tentang BUM-Nag sebagai salah satu strategi, yang sangat relavan untuk diterapkan. Karena penggunaan strategi ini bertujuan untuk meningkatkan kinerja pemerintah Nagari dalam pelaksanaan tugas pokok dan fungsinya, dengan perhatian fokus pada dimensi: (1) pengembangan kualitas sumber daya manusia baik melaui pendidikan atau pelatihan; (2) meningkatkan penguatan kelembagaan; dan (3) hasil pengembangan inovasi dan reformasi birokrasi.

Beberapa permasalahan yang dihadapi oleh mitra dalam menyusun dan menetapkan rancangan peraturan nagari tentang pengelolan BUM-Nag di Nagari Tabek Patah dan Nagari Situmbuk pada Kecamatan Salimpaung Kabupaten Tanah Datar adalah:

1) Pertama, kurangnya kapasitas para pemaku kepentingan (stake holder) pada Aparatur Nagari untuk memahami peraturan perundang-undangan dan peraturan daerah terkait sebagai dasar dalam pembuatan dan pengelolaan BUM-Nag. Kapasitas tersebut dibutuhkan agar BUM-Nag yang dibuat tidak bertentangan dan sesuai dengan peraturan yang ada.

2) Kedua, kurangnya pemahaman dan pengetahuan (capacity building) terhadap konsep penguatan kelembagaan BUM-Nag;

3) Ketiga, rendahnya pemahaman dan pengetahuan (capacity building) aparatur nagari dalam kepengurusan dan manajemen BUM-Nag;

4) Keempat, kurangnya pengetahuan dan pemahaman aparatur tentang pemanfaatan potensipotensi daerah yang ada di Nagari yang dapat dijadikan sebagai sumber pemasukan Nagari atau aset Nagari dan dijadikan BUM-Nag;

5) Kelima, kurangnya pembinaan dan pendampingan dari insitusi setempat untuk meningkatkan kapasitas Aparatur dalam menyusun, merumuskan, menetapkan dan mengelola BUM-Nag. 


\section{METODE}

Metode pendekatan yang digunakan dalam pemecahan sebuah masalah yang sebelumnya sudah dirumuskan dan teridentifikasi menggunakan pendekatan pendekatan dan pelatihan "participatory rural appraisal" yang berpedoman pada prinsip partisipatoris yaitu lebih menekankan pada asas peran dan keterlibatan lansung seluruh peserta pelatihan untuk memudahkan dalam tercapainya suatu sasaran dan tujuan telah ditetapkan. Langkah awal pelatihan ini dengan cara mensurvey serta menetapkan sebuah tujuan dan sasaran yang ingin dicapai. Selain itu pendekatan lain yang digunakan dalam kegiatan ini adalah menggunakan teknik dan metode survey, metode diskusi, dialog, ceramah, dan pendampingan.

1) Survey tentu sangat perlu dilakukan guna mencari tahu dan mengidentifikasi apa saja yang menjadi faktor penghambat dan peluang serta melihat apa saja yang kira-kira potensi yang dapat digali dan dikembangkan serta dimanfaatkan sebagai pemasukan pendapatan Nagari;

2) Ceramah dilakukan dengan cara memberikan penyampaian materi yang berkaitan dengan topik/tema pengabdian yaitu materi tentang BUM-Nag. Materi disampaikan dalam bentuk forum diskusi antara pemateri dan kelompok masyarakat yang menjadi sasaran dari kegiatan ini;

3) Diskusi dan dialog dilakukan dengan tujuan untuk memberikan informasi kepada tim peneliti dan mengetahui sejauh mana tingkat pemahaman masyarakat terkait dengan pemaparan materi dan tentang masalah atau kendala apa yang dihadapi dalam rangka menjalankan BUM-Nag;

4) Metode brainstorming ini adalah sebuah proses pengumpulan gagasan-gagasan bersama untuk dijadikan suatu inventarisasi terhadap gagasan yang telah dikemukakan. Brainstorming dilakukan pada topik materi peningkatan fungsi dan tugas unsur Kelembagaan Nagari dalam menyusun produk BUM-Nag;

5) Pendampingan dan praktik akan digunakan untuk mengetahui seberapa besar tingkat potensi-potensi yang dimiliki oleh Nagari Situmbuk dan Nagari Tabek Patah yang kemudian jika memungkinkan bersama masyarakat dan stake holder untuk membentuk Badan Pengurus BUM-Nag baru yang sekaligus akan ditetapkan dan tertuang dalam sebuah Surat Keputusan Wali Nagari, yang merupakan wujud dari penguatan kelembagaan adanya BUM-Nag di nagari tersebut. Dan pada tahapan selanjutnya akan dilakukan sebuah pendampingan terhadap kepengurusan pengelolaan BUM-Nag;

6) Teknik dan metode yang digunakan selain untuk memberikan tingkat pemahaman mengenai pengelolaan dan manajemen BUM-Nag, juga bersama-sama pemerintah Nagari dan bersama tokoh masyarakat (stake holder) terkait untuk menyusun dan merumuskan peraturan nagari tentang pendirian BUM-Nag. Partisipasi mitra pada kegiatan program pengabdian masyarakat ini merupakan sebagai khalayak sasaran yang terlibat lansung dan berpartisipasi lngsung dalam penyuluhan dan pelatihan. Anggota unsur Nagari Nagari Situmbuk dan Nagari Tabek Patah yang terlibat secara lansung pada kegiatan diantarnya: Wali Nagari, Bamus, Stake Holder yang terlibat dalam kegiatan pengabdian ini diperkirakan sekitar 40 peserta yang akan dilaksanakan pada satu lokasi, dengan mendatangkan pakar atau ahli dibidang BUMNag, dengan 4 pemateri inti setiap kegiatan dilakukan. 
Adapun yang menjadi target/solusi pemecahan permasalahan pada mitra terlihat pada gambar dibawah ini:

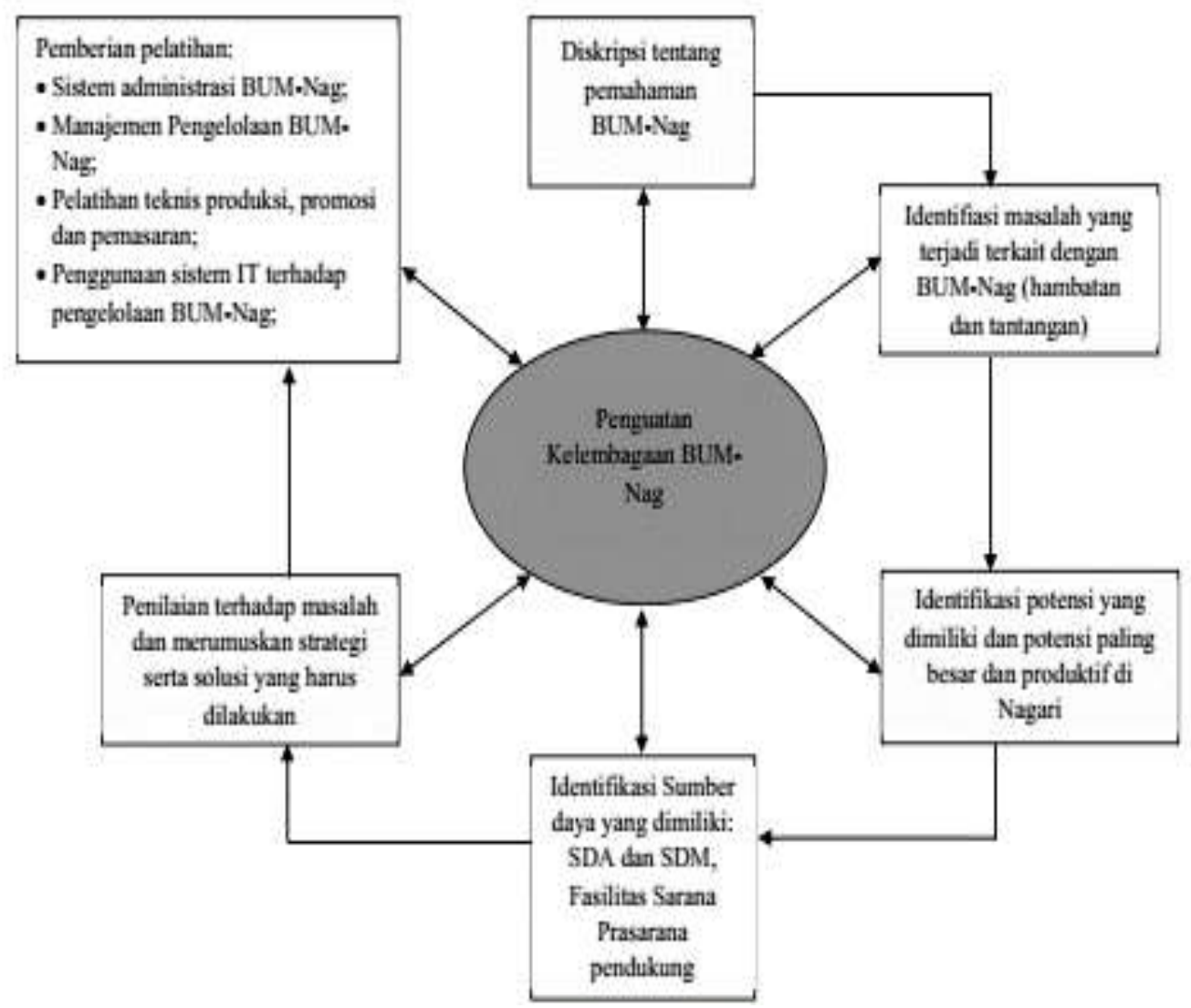

Gambar 1. Gambaran Solusi Pemecahan Permasalahan Mitra

\section{HASIL DAN PEMBAHASAN}

Beberapa hasil yang didapatkan dari kegiatan pengabdian TIM Pengabdi Jurusan Ilmu Administrasi Negara Universitas Negeri Padang terhadap Nagari Situmbuk dan Nagari Tabek Patah di Kecamatan Salimpaung dapat dijelaskan beberapa urutan kegiatan yang telah kami lakukan. Pada tahap persiapan TIM melakukan beberapa persiapan untuk melakukan kegiatan pegabdian ini diantara tahap persiapan itu adalah, merumuskan proposal, mencari daerah mitra dan meminta kerjasamanya untuk melakukan kegiatan pengabdian ini. Masih dalam tahap persiapan Kegiatan TIM selanjutnya adalah mengurus surat izin ke kantor Kesbangpol Tanah datar dan menindak lanjutinya ke lokasi pengabdian, seperti menentukan jadwal dan mensosialisasikan proposal kegiatan ke aparatur pemerintahan nagari.

Setelah tahap persiapan selesai selanjutnya adalah pelaksanaan kegiatan pengabdian, pelaksanaan kegiatan pengabdian ini kami lakukan pada dua tempat dan dilakukan pada waktu yang berbeda dengan peserta yang berbeda pula. Kegiatan pertama dilaksanakan pada tanggal 29 agustus 2019 di Gedung Aula Pemerintah Nagari Tabek Patah Kab. Tanah Datar, kegiatan kedua dilakukan pada tanggal 15 september 2019 di Gedung Aula Pemerintah Nagari Situmbuk Kab. Tanah Datar. 


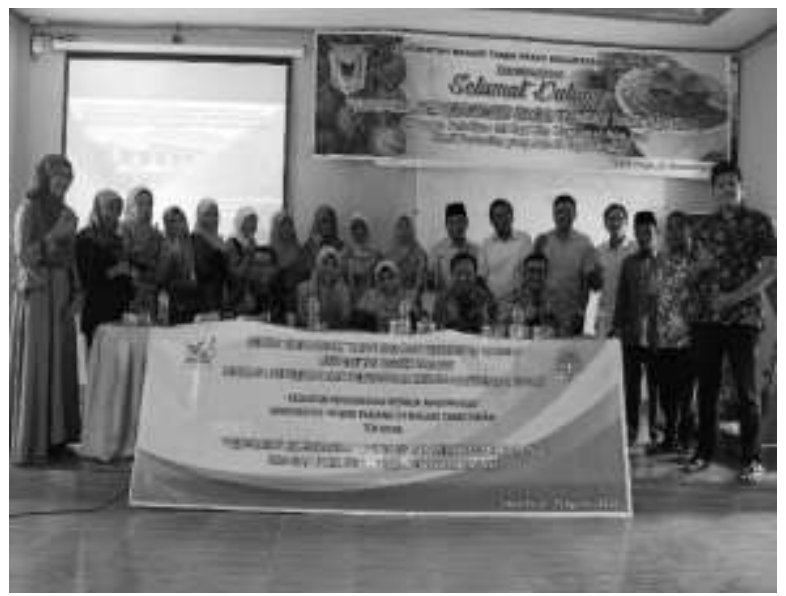

(a)

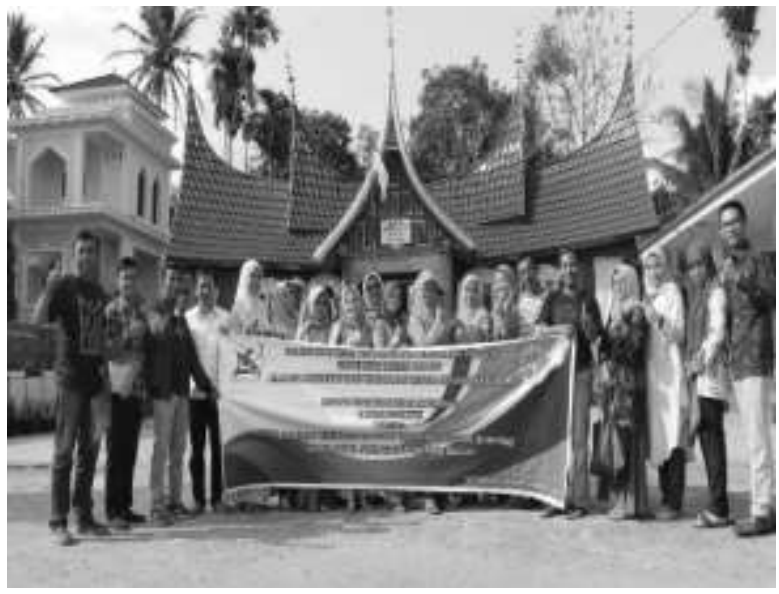

(b)

Gambar 2. (a) Pengabdian di Nagari Tabek Patah (29/8/2019) dan (b) Pengabdian di Nagari Situmbuk $(15 / 9 / 2019)$

Kegiatan tersebut dihadiri oleh lebih kurang 25 orang peserta yang semua pesertanya adalah orang-orang yang terlibat dalam BUM-Nag, mulai dari pengurus inti pemerintahan nagari, kepengurusan BUM-Nag, dewan pengawas dan lembaga usur lainya. Kegiatan pengabdian ini adalah kegiatan yang terdiri 3 tahapan kegiatan, kegiatan ini dilakukan berdasarkan jumlah pemateri yang dihadirkan dalam kegiatan.

Materi yang kami sajikan untuk kegiatan pengabdian meliputi: 1) Penguatan Kelembagan Badan Usaha Milik Nagari (BUM-Nag); 2) Menggerakkan Perekonomian Nagari Melalui Badan Usaha Milik Nagari (BUM-Nag) Sustainable; dan 3) Strategi Pengelolaan BUM-Nag.

\section{1) Penguatan Kelembagan Badan Usaha Milik Nagari (BUM-Nag)}

Pembentukan BUM-Nag atau disebagian besar daerah pada Provinsi lain dikenal dengan BUM-Des merupakan tindakan nyata dari amanat Undang-undang Nomor 6 tahun 2014 tentang Desa, dimana pemerintah Nagari/Desa sebagai bentuk pemerintahan tingkat terrendah dituntut secara mandiri untuk mampu menggali potensi-potensi kekayaan yang ada didaerah Nagarinya untuk dijadikan sebagai aset dan sumber pemasukan keuangan Nagari, serta dituntut mampu melaksanakan pengelolaan keuangan Nagari secara mandiri. Landasan hukum pendirian BumNag diantaranya adalah Undang-Undang Nomor 32 tahun 2004 tantang Pemerintahan Daerah, Undang-Undang No 6 tahun 2014 tantang Desa yang kemudian dipertegas dengan adanya Peraturan Pemerintah Nomor 72 Tahun 2010 Tentang Desa, Peraturan Menteri dalam Negeri nomor 39 tahun 2010 tentang Badan Usaha Milik Desa (BUMDes), Peraturan Bupati Tanah Datar Nomor 5 Tahun 2016 tentang pedoman pendirian, pengurusan, pengelolaan dan pembubaran badan usaha milik Nagari dan dilanjutkan dengan Peraturan Nagari nomor 500/52/SK/WNSTB/2018 tetang Penetapan Pengurus Badan Usaha Milik Nagari (BUM-Nag) dan Badan Pengawas Nagari Situmbuk Kecamatan Salimpaung.

Sedangkan landasan filosofi berdirinya BUM-Nag meliputi:

a) Perwujudan peningkatan pelayanan publik bagi pengembangan usaha mikro berdasarkan kebutuhan masyarakat dan potensi desa untuk kesejahteraan bersama;

b) Pengembangan sarana penciptaan lapangan kerja dan media pemberdayaan ekonomi kerakyatan;

c) Pengembangan wahana dalam perkuatan basis pajak dan retribusi guna meningkatkan pendapatan asli desa. 
Berdirinya sebuah Bum-Nag bertujuan agar setiap Nagari mampu untuk mandiri secara ekonomi dan keuangan dan diharapkan nagari amampu untuk meningkatkan kesejahteraan masyarakat yang ada di Nagarinya, karena pada hakikatnya masyarakat akan lebih mudah berkembang sesuai dengan potensi-potensi yang dimilikinya. Berikut adalah bagan dari model model penguatan ekonomi nagari melalui peran Bum-Nag.

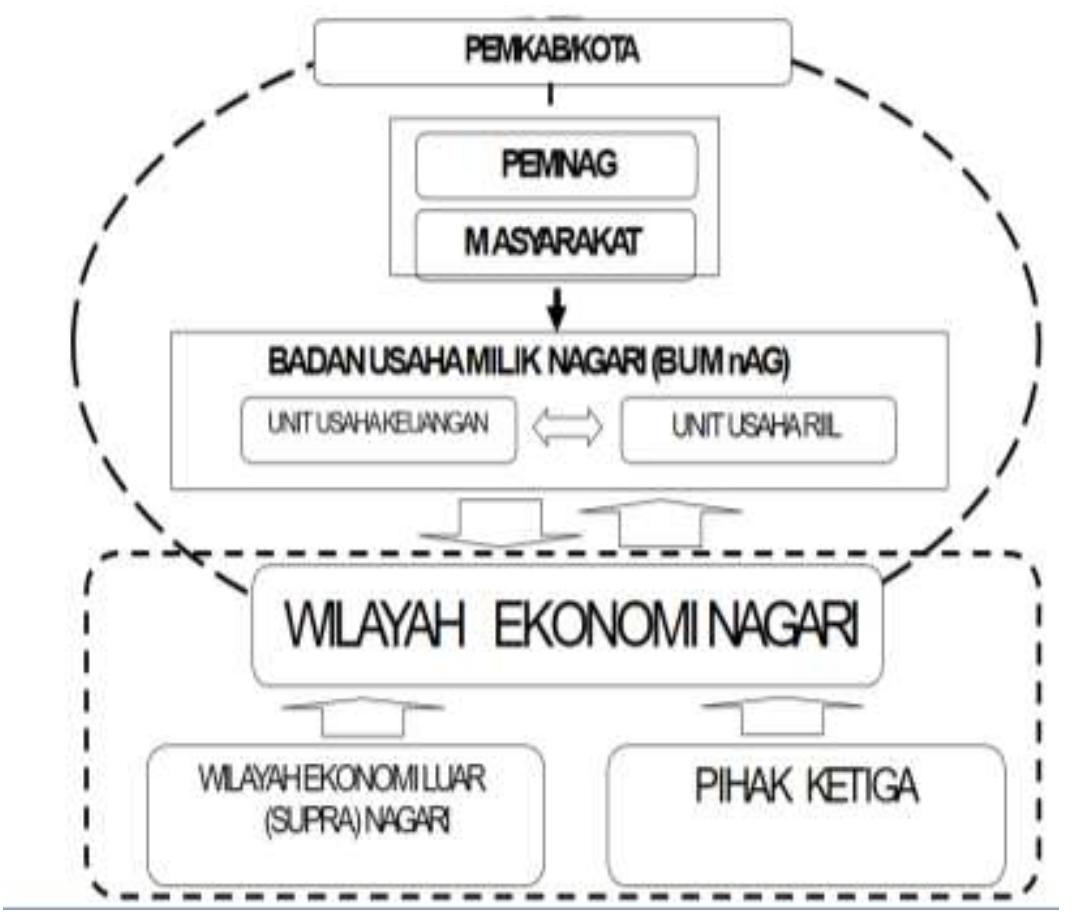

Gambar 3. Model Penguatan Ekonomi Nagari Melalui Peran Bum-Nag

\section{2) Menggerakkan Perekonomian Nagari Melalui BUM-Nag Sustainable}

Nagari sebagai bentuk dari satu kesatuan masyarakat yang berdikari dan mandiri (otonom), tentunya memiliki potennsi daerah dan sumber kekayaan yang dapat digali, dimanfaatkan dan dikelola secara baik dan professional oleh daerah. BUM-Nag merupakan salah satu badan usaha alternative, sudah saatnya untu dikembangakan untuk peningkatan perekonomian Nagari, dengan harapan dapat menciptakan sumber pendapatan baru bagi Nagari untuk mensejahterakan ekonomi masyarakat Nagari. BUM-Nag memiliki nilai transformasi sosial, ekonomi dan budaya. Hal inilah yang menjadikan BUM-Nag sebagai salah satu lembaga ekonomi rakyat yang berperan sebagai pilar demokrasi ekonomi. BUM-Nag sebagai pilar demokrasi ekonomi setidaknya meliputi:

a) BUM-Nag sebagai lembaga ekonomi masyarakat yang berperan strategis untuk menggairahkan ekonomi Nagari;

b) Keunikan BUM-Nag yakni merupakan sebuah usaha Nagari milik kolektif yang digerakkan oleh aksi kolektif antara pemerintah Nagari dan masyarakat (Public and Community Partnership);

c) BUM-Nag dibentuk atas dasar komitmen bersama masyarakat Nagari untuk saling bekerja sama dan menggalang kekuatan ekonomi rakyat demi mewujudkan kesejahteraan dan kemakmuran masyarakat Nagari. Pengembangan dan pembentukan BUM-Nag merupakan prospek menjanjikan untuk menguatkan dan memberdayakan lembaga-lembaga ekonomi Nagari.

Materi tentang menggerakkan perekonomian nagari melalui BUM-Nag sustainable dasampaikan oleh Ibu Dra. Jumiati, M.Si dan Ibu Yuliarti, S.E., M.E dan diikuti oleh para peserta 
dan juga teruskan dengan sesi diolog/diskusi dan sesi tanya jawab, seperti terlihat pada gambar dibawah ini:

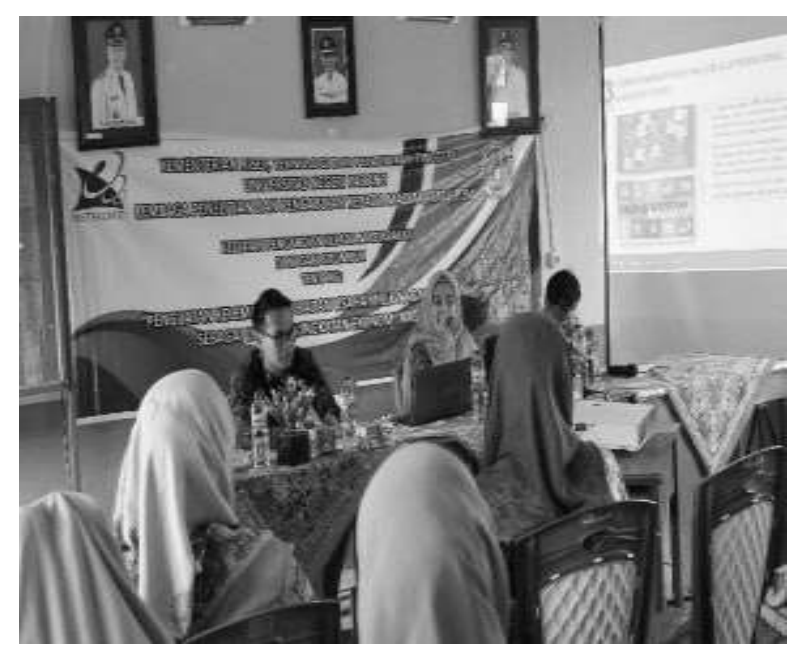

(a)

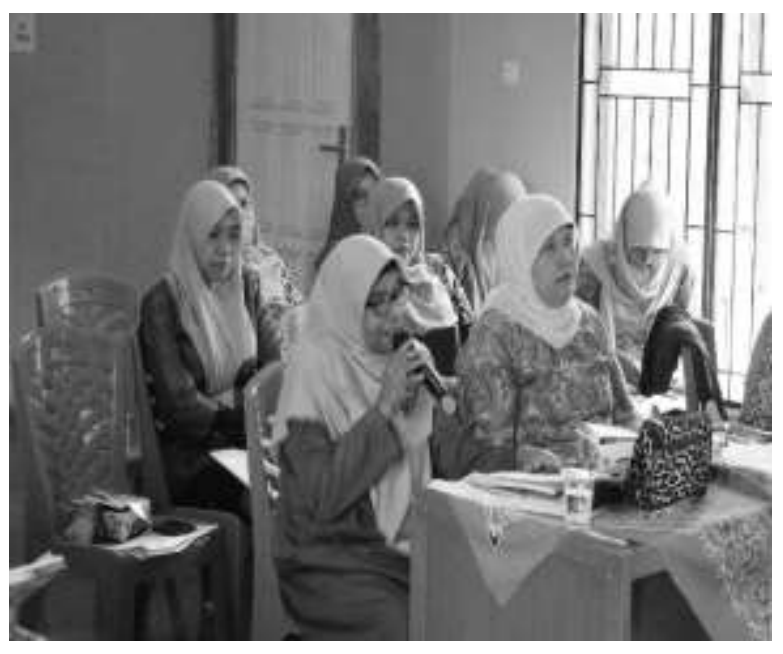

(b)

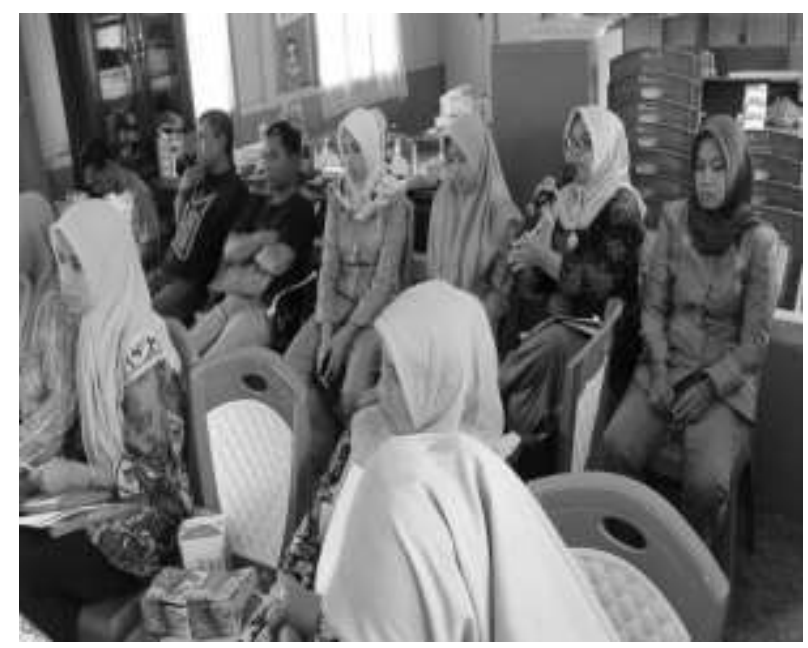

(C)

Gambar 4. (a) Penyampaian Materi dan (b, c) Sesi diskusi dan tanya jawab

\section{3) Strategi Pengelolaan Badan Usaha Milik Nagari (BUM-Nag)}

Dalam menjalankan BUM-Nag tentunya kita harus memiliki strategi. Strategi bertujuan untuk mencapai hasil semaksimal sesuai dengan tujuan bersama. Beberapa strategi yang disampaikan oleh pemateri Bapak Aldri Frinaldi, Ph.D dan Boni Saputra, S.AP., MPA dalam mengelolaan BUM-Nag adalah:

a) Kenali apa yang menjadi kebutuhan dan potensi daerah

- Kenali kebutuhan masyarakat terutama dalam pemenuhan kebutuhan pokok;

- Sumberdaya Nagari yang belum dimanfaatkan secara optimal, terutama kekayaan Nagari;

- Sumberdaya manusia yang mampu mengelola badan usaha sebagai aset penggerak perekonomian masyarakat;

- Unit-unit usaha masyarakat yang merupakan kegiatan ekonomi warga masyarakat yang dikelola secara parsial dan kurang terakomodasi.

b) Sumber daya pembangunan perekonomian nagari

- Sumber daya manusia (SDM);

- Sumber daya alam (SDA);

- Sarana dan prasarana kelembagaan 
c) Merencenakan Pembentukan BUM Nag

- Mendesain kebijakan Nagari

- Menemukan dan mengembangkan strategi sesuai kharakteristik Usaha

- Menyusun AD/ART

- Membentuk Kepengurusan

d) Melakukan analisis SWOT untuk mendapatkan strategi efektif dalam mengelola BUM-Nag

Selain strategi ada lagi yang namanya agenda pengelolan yang harus diperhatikan dalam mengelola BUM-Nag. Agenda dalam pengelolan BUM-Nag tersebut meliputi:

1) Memahami potensi dan kapasitas Nagari (kluster) yang menjadi faktor kendala dan pendukung utama dalam menunjang kegiatan ekonomi produktif masyarakat Nagari;

2) Memahami karakteristik pola perilaku sosial (social behaviour) masyarakat Nagari dalam melaksanakan kegiatan ekonomi produktif nagari;

3) Memahami kebutuhan masyarakat Nagari terhadap BUM-Nag yang sesuai dengan karakteristik potensi, kapasitas, dan masyarakat Nagari dalam memandirikan ekonomi Nagari;

4) Memahami tatacara pengelolaan BUM-Nag yang sesuai dengan kondisi lokal masyarakat Nagari;

5) Menyusun desain model pendirian dan pengelolaan BUM-Nag, serta sosialisasi, pelatihan, dan pendampingannya;

6) Mendiseminasikan potensi dan kapasitas Nagari yang menjadi faktor kendala dan pendukung utama dalam menunjang kegiatan ekonomi produktif masyarakat Nagari;

7) Mendiskusikan karakteristik pola perilaku sosial (social behaviour) masyarakat Nagari dalam melaksanakan kegiatan ekonomi produktif Nagari;

8) Mendiskusikan kebutuhan dan keinginan masyarakat Nagari berkenaan dengan pendirian dan pengelolaan BUM-Nag;

9) Mensepakati tentang bentuk struktur organisasi BUM-Nag yang mampu mengakomodasi kepentingan masyarakat Nagari;

10) Mensepakati bentuk "legal drafting" di tingkat kabupaten ;

11) Menyusun Pedoman sebagai rujukan mendirikan dan mengelola BUM-Nag.

\section{KESIMPULAN}

Dari hasil kegiatan pengabdian ini, dapat disimpulkan bahwa tema pegabdian ini sangat lah cocok di berikan kepada aparatur pemerintahan dan stake holder terkait BUM-Nag di Nagari Situmbuk dan Nagari Tabek Patah Kecamatan Salimpaung. Hal ini dikarenakan oleh belum pahamnya aparatur pemerintahan nagari dan stake holder terkait di Nagari Situmbuk dan Nagari Tabek Patah Kecamatan Salimpaung terhadap penguatan kelembagaan Badan Usaha Milik Nagari (BUM-Nag). Hal ini dibuktikan dengan belum berjalanya BUM-Nag yang ada di Nagari Situmbuk. Di Nagari Situmbuk sudah ada peraturan nagari nomor 500/52/SK/WN-STB/2018 tetang Penetapan Pengurus Badan Usaha Milik Nagari (BUM-Nag) dan Badan Pengawas Nagari Situmbuk Kecamatan Salimpaung akan tetapi hingga saat ini BUM-Nag yang dibentuk belum berjalan sebagaimana mestinya, karena pihak pemerintah Nagari belum ada menganggarkan atau mengalokasikan dana untuk kegiatan BUM-Nag tersebut, dan belum adanya kejelasan terkait penyertaan modal yang dimiliki. Sementara di Nagari Tabek Patah, mereka sudah memiliki BUMNag yang bernama "Tabek Makmur" dan sudah berjalan kurang lebih selama satu tahun, akan tetapi yang menjadi permasalahan adalah pihak Nagari hanya terfokus pada BUM-Nag satu bidang saja yaitu bidang usaha penjualan ATK dan jasa fotocopy, sementara Nagari Tabek Patah masih banyak memiliki potensi lainya yang bisa dikembangkan dan dikelola menjad BUM-Nag, seperti bidang pariwisata, hasil pertanian/perkebunannya. 
Hal lain yang bisa kami simpulkan selama melakukan kegiatan pegabdian di Nagari Situmbuk dan Nagari Tabek Patah Kecamatan Salimpaung, masih kurangnya pemahaman pemerintahan nagari dan stake holder terkait tentang penguatan kelembagaan Badan Usaha Milik Nagari (BUM-Nag) sebagai upaya Peningkatan Ekonomi Nagari, sehingga masih perlu banyak pemahaman yang diberikan kepada aparatur pemerintahan nagari dan stake holder terkait tentang kelembagaan BUM-Nag dan pengelolaanya, sehingga aparatur pemerintahan nagari bisa menjalankan tugasnya dan mampu mengelola aset nagarinya melalui BUM-Nag yang dimilikinya dengan lebih baik lagi kedepannya.

Sementara itu saran yang ingin kami sampaikan adalah Pemerintahan nagari dan stake holder terkait BUM-Nag di Nagari Situmbuk dan Nagari Tabek Patah Kecamatan Salimpaung hendaknya bisa menambah pengetahuan lagi terkait penguatan kelembagaan dan pengelolaan Badan Usaha Milik Nagari (BUM-Nag) yang dimilikinya. Pemerintahan Nagari Situmbuk dan Nagari Tabek Patah mungkin bisa melakukan brainstorming dengan nagari-nagari yang sudah berhasil membuat dan mengimplementasikan BUM-Nag, sehingga pemerintahan nagari Nagari Situmbuk dan Nagari Tabek Patah juga mempunyai produk baru melalui BUM-Nag yang nantinya akan berdampak pada kemandirian dan peningkatan ekonomi Nagari yang nantinya berguna untuk kesejahteraan masyarakat nagari tersebut.

\section{UCAPAN TERIMA KASIH}

Salam dan ucapan terima kasih, penulis haturkan teruntuk LP2M Universitas Negeri Padang atas bantuan dana yang diberikan, melalaui pendanaan DIPA UNP Pengabdian Kepada Masyarakat program kemitraan masyarakat tahun anggaran 2019 berdasarkan surat Keputusan Nomor 238.a/UN35/PM/2019 dan Perjanjian Kontrak Nomor 1328/UN35.13/PM/2019, seterusnya penulis juga mengucapkan terima kasih kepada pihak pemerintahan Tabek Patah dan Nagari Situmbuk pada Kecamatan Salimpaung, Kabupaten Tanah Datar yang menjadi tempat dilaksanakannya pengabdian masyarakat ini serta ucapan terima kasih kepada tim pengabdi dan para narasumber sehingga pengabdian kepada masyarakat ini dapat diselesaikan tepat pada waktunya.

\section{DAFTAR PUSTAKA}

Anwar, S. M., Goso, \& Adil. (2017). Penguatan Ekonomi Desa melalui BUMDES di Desa Poreang Kecamatan Tana Lili Kabupaten Luwu Utara Sulawesi Selatan. Resona Jurnal Ilmiah Pengabdian Masyarakat, 1(1), 6-12.

Astuti, E., Murwani, J., \& Sugiharto. (2020). Pelatihan Akuntansi Pemerintahan dan Pengelolaan Dana Desa Pada MGMP Kabupaten Madiun. DINAMISIA Jurnal Pengabdian Kepada Masyarakat, 4(2), 214-221. Retrieved from https://journal.unilak.ac.id/index.php/dinamisia/article/view/3593/2184

Hadi, B. (2015). Tantangan Penerapan Kurikulum Akuntansi Pemerintahan untuk SMK Kelompok Keahlian Bisnis dan Manajemen dengan Adanya UU Desa Nomor 6 Tahun 2014. Seminar Nasional Pendidikan Akuntansi Dan Keuangan "Pengembangan Pendidikan Akuntansi Dan Keuangan Yang Berkelanjutan", 564-573. Retrieved from https://doi.org/10.1017/S026502150623028X

Karim, A. A. (2007). Ekonomi Makro Islami. Jakarta: Raja Grafindo Persada.

Kolne, Y., \& Festianto, D. (2018). Pendampingan Pembentukan Badan Usaha Milik Desa di Desa Napan, Bikomi Utara, Timor Tengah Utara. Bakti Cendana Jurnal Pengabdian Masyarakat, 1(1), 19-24.

Peraturan Bupati Tanah Datar Nomor 5 Tahun 2016 tentang pedoman pendirian, pengurusan, pengelolaan dan pembubaran badan usaha milik Nagari. , (2016).

Pradesyah, R., \& Albara. (2018). Pengelolaan Potensi Badan Usaha Milik Desa (Bumdes) 
Berbasis Syariah di Desa Rambung Sialang Hulu Kecamatan Sei Rampah Kabupaten Serdang Bedagai Sumatera Utara. Jurnal Prodikmas, 2(2), 156-164.

Sayuti, M. (2011). Pelembagaan Badan Usaha Milik Desa (BUMDes) sebagai Penggerak Potensi Ekonomi Desa dalam Upaya Pengentasan Kemiskinan dikabupaten Donggala. Jurnal ACADEMICA FISIP UNTAD, 3(2).

Sofiani, V., Saepuloh, L., \& Eriswanto, E. (2016). Pemberdayaan Ekonomi Desa Melalui Badan Usaha Milik Desa (BUMDes) Desa Karangjaya Kecamatan Gegerbitung Kabupaten Sukabumi. Prosiding Seminar Nasional Dan Call for Paper "Pengembangan Sumber Daya Perdesaan Dan Kearifan Lokal Berkelanjutan VI." Purwokerto.

Solekhan, M. (2014). Penyelenggaraan Pemerintahan Desa Berbasis Partisipasi Masyarakat. Malang: Setara Press.

Sulistyani, A. T. (2004). Kemitraan dan Model-Model Pemberdayaan. Yogyakarta: Gava Media. Undang-undang Nomor 6 Tahun 2014 Tentang Desa. , (2014). 